\title{
The quest for reasonable retail energy prices in Europe: positive and normative dimensions
}

Article

Accepted Version

Mantzari, D. (2017) The quest for reasonable retail energy prices in Europe: positive and normative dimensions. Yearbook of European Law, 36 (1). pp. 599-627. ISSN 2045-0044 doi: https://doi.org/10.1093/yel/yex016 Available at https://centaur.reading.ac.uk/73763/

It is advisable to refer to the publisher's version if you intend to cite from the work. See Guidance on citing.

To link to this article DOI: http://dx.doi.org/10.1093/yel/yex016

Publisher: Oxford University Press

All outputs in CentAUR are protected by Intellectual Property Rights law, including copyright law. Copyright and IPR is retained by the creators or other copyright holders. Terms and conditions for use of this material are defined in the End User Agreement.

www.reading.ac.uk/centaur 
Central Archive at the University of Reading

Reading's research outputs online 


\title{
THE QUEST FOR REASONABLE RETAIL ENERGY PRICES IN EUROPE: POSITIVE AND NORMATIVE DIMENSIONS
}

\author{
DESPOINA MANTZARI
}

\begin{abstract}
Public opinion in various EU Member States increasingly perceives energy prices as unreasonable. Primarily owing to distributional concerns, state interference with the liberalised retail energy market is ever-present across many EU Member States, despite its implications for the development of competitive (national and EU) energy markets. Rather than solely engaging with the conditions of state intervention as such, this article takes a step back and argues that an appreciation of what constitutes a reasonable price for energy supply is a necessary prerequisite in determining the relevance, scope and conditions of state intervention in retail energy prices. In the absence of a definition of the concept in secondary legislation, it offers a novel conceptual framework centred on the contextual interpretation of "a reasonable price for energy supply". The article offers two understandings of reasonableness: one underpinned by the principle of market competition and the other understood as affordability. It elaborates on the different set of conditions and criteria against which they are judged and it explains how these have informed various instruments enshrined in the energy liberalisation directives for achieving reasonable prices for end-consumers. These range from consumer empowerment measures to more direct consumer protection measures informed by affordability concerns. After providing a taxonomy of the latter instruments, it examines their respective advantages and disadvantages by focusing on how these are perceived by the EU framework. Its broader aim is to contribute to a more nuanced understanding of what is meant by a "reasonable retail energy price" within the context of national and EU competitive retail energy markets and explore how the resulting tension between the two understandings of reasonableness is accommodated in the broader EU constitutional and institutional context.
\end{abstract}

\footnotetext{
* Lecturer in Law, University of Reading. Email: d.mantzari@reading.ac.uk. I thank Ioannis Lianos, Chris Hilson, Maria Ioannidou, an anonymous reviewer as well as participants at the $9^{\text {th }}$ IMEDIPA Conference for Competition Law and Policy and the 2017 Society of Legal Scholars Conference for helpful comments and discussions on earlier versions of this paper. Some of the research on which this paper draws has been funded by a BA/Leverhulme Small Research Grant (Grant No: H5234700); the British Academy's support is gratefully acknowledged. Any views expressed, omissions or mistakes are mine.
} 


\section{Introduction}

Over the past decade, retail energy prices (electricity and gas) in several EU Member States have generated a considerable amount of public and political debate and justifiably so. Household energy bills have typically increased in recent years raising concerns in relation to energy affordability. ${ }^{1}$ In the EU, on average household electricity prices have increased more than $4 \%$ a year for the last five years ${ }^{2}-$ an increase above inflation while for industrial consumers they have increased by about $3.5 \%$ a year. ${ }^{3}$ For gas, household prices have risen 3\% a year, again above inflation, for most Member States. ${ }^{4}$ Moreover, while almost all Member States have seen a consistent rise in the consumer prices of electricity and gas, the differences between different national prices remain large: "consumers in the highest priced Member States are paying 2.5 to 4 times as much as those in the lowest priced Member States". 5 This has led to the unfortunate situation where consumers in many EU Member States, especially in hard-pressed households, struggle to pay their energy bills. Increasingly, public opinion perceives the prices paid for keeping the lights and heating on as unreasonable.

Given the above, it is timely to consider the underexplored question of what constitutes a reasonable price for electricity and gas in the current EU paradigm of liberalized retail energy markets. As things stand today, the level of retail prices is no longer the province of the government or the regulator, as was the case when stateowned, vertically integrated monopolies dominated national energy markets, but is determined by the degree of competition between energy supply companies. ${ }^{6}$ Though the

1 See VaasaETT, "European Residential Energy Pricing Report" (2014) available at $<$ http://www.energypriceindex.com/wp-content/uploads/2016/08/European-Residential-Energy-PriceReport-2014.pdf > (last visit 10 October 2017).

${ }^{2} \operatorname{COM}(2014) 21 / 2$, "Communication from the Commission to the European Parliament, the Council, the European Economic and Social Committee and the Committee of the Regions: Energy Prices and Costs in Europe", at 14.

${ }^{3}$ Ibid., 5.

${ }^{4}$ Ibid., 5 .

${ }^{5}$ Ibid., 4.

${ }^{6}$ The liberalization took place in three phases: In the first phase, the retail market opened to facilitate energy supply to large-scale, industrial end-users and from 1 July 2004, to all non-household customers, see Art. 19 of Directive (96/92/EC) of 19 December 1996 concerning common rules of the internal market in electricity, O.J. 1996, L 27/20 and Art. 18 of Directive (98/30/EC) of 22 June 1998 concerning common rules for the internal market in natural gas, O.J. 1998, L 204/1. During the second phase, as the result of the Second Energy Package, the energy sector opened up for all end-users, including household customers 
EU energy acquis repeatedly refers to the objective of ensuring reasonable prices for electricity and gas, the concept is not defined anywhere in the text of the energy liberalisation directives. Nor do the directives contain a set of criteria against which one can judge the reasonableness of energy prices. For example, should a price be deemed reasonable solely in relation to the underlying wholesale costs or should one also take into account the consumer's willingness and/or ability to pay? And, which type of consumer, given the different images of energy consumers enshrined in the energy directives (i.e. household customers, industrial customers, vulnerable consumers)? ${ }^{7}$

The question is also significant given the ever-present political interest in the level of energy prices manifested, inter alia, by the pervasiveness of retail price regulation in several EU Member States $;^{8}$ despite ambitions that retail energy liberalization would reduce state interference in the energy market. ${ }^{9}$ For example, in the UK, which has led the way in the EU in terms of energy market liberalization, the pursuit of reasonable prices has led to controversial proposals, such as an energy price freeze, ${ }^{10}$ and other short-term regulatory interventions ${ }^{11}$ with - often - unintended consequences. ${ }^{12}$ Such

since 1 July 2007, see Art. 2 (12) and 21 of Directive (2003/54/EC) of the European Parliament and of the Council of 26 June 2003 concerning common rules for the internal market in electricity and repealing Directive (96/92/EC), O.J. 2003, L 176/37 and Art. 2 (28) and 23 of Directive (2003/55/EC) of the European Parliament and the Council 26 June 2003 concerning common rules for the internal market in natural gas and repealing Directive (98/30/EC), O.J. 2003, L 176/57. Retail competition is strengthened by virtue of the Third Energy Package provisions that are currently the applicable law, see Directive (2009/72/EC) of the European Parliament and of the Council of 13 July 2009 concerning common rules for the internal market in electricity and repealing Directive (2003/54/EC), O.J. 2009, L 211/55 (hereinafter referred to as "Electricity Directive 2009/72/EC") and Directive (2009/73/EC) of the European Parliament and the Council of 13 July 2009 concerning common rules for the internal market in natural gas and repealing Directive (2003/55/EC), O.J. 2003, L 211/94 (hereinafter referred to as "Gas Directive 2009/73/EC").

${ }^{7}$ See Lavrijssen, "The Different Faces of Energy Consumers: Toward a Behavioral Economics Approach", 10(2) JCL\&E (2014), 257-291.

${ }^{8}$ See ACER/CEER, "Annual Report on the Results of Monitoring the Internal Electricity and Gas Markets in 2015" (November 2016) available at:

<http://www.ceer.eu/portal/page/portal/EER_HOME/EER_WORKSHOP/CEERERGEG\%

20EVENTS/CROSS_SECTORAL/ACER_CEER_MMR_2016/Event\%20Information>, at p. 46 (last accessed 10 October 2017).

${ }^{9}$ Prosser, Nationalised Industries and Public Control (Blackwell, 1986).

10 Ed Miliband, 2013, "Labour would freeze energy prices" 24th September 2013, http://www.bbc.co.uk/news/uk-politics-24213366 (last visit 19 May 2017). For a criticism see C Waddams, "Price Regulation is not the Solution to Unaffordable Energy Prices" (CCP Blog post 2013) available at $<$ https://competitionpolicy.wordpress.com/2013/09/25/price-regulation-is-not-the-solution-to-unaffordableenergy-prices/> (last visit 10 October 2017).

${ }^{11}$ See e.g. in the UK context, the prohibition of regional price discrimination through Standard Licence Condition SLC 25A in 2009. 
interventionist measures recently resurfaced during the UK election campaign, with the UK Conservative party suggesting an absolute price cap on standard variable tariffs. ${ }^{13}$ "[T]he irresistible urge to meddle" 14 with the energy retail market is primarily owing to post-financial crisis inequality concerns and broader distributional concerns: while competition may be the best way to ensure the lowest average prices and the highest quality for consumers on average, it is a process that barely guarantees any equality of outcome-there will be "winners" and "losers"; assuming, of course, that there is sufficient competition. Those consumers who loose from the competitive process may not be "empowered" enough to engage with the market and switch to better deals and/or may be "vulnerable", and thus not "protected" enough. It has always been difficult to distinguish between these two categories, not least because, as we shall see, disengaged consumers often exhibit characteristics of vulnerability.

Against this backdrop, this article argues that before embarking on a normative inquiry around the appropriateness and nature of state intervention in retail energy prices, one should first appreciate what precisely constitutes a reasonable price for energy supply. For a better understanding of the concept in all its variations is crucial for determining the relevance of state intervention as well as the proper scope of the various instruments provided by the EU energy acquis for achieving reasonable prices.

In the absence of a definition of the concept in secondary legislation, the article offers a novel conceptual framework centred on the contextual interpretation of "a reasonable price for energy supply". In particular, the framework is informed by the overarching objectives and underlying principles of the EU energy acquis, as well as by the broader constitutional significance of energy supply as a service of general economic interest

\footnotetext{
12 For an analysis of the anticompetitive effects of the SLC 25A see Hviid and Waddams, "NonDiscrimination Clauses in the Retail Energy Sector" 122 (562) The Economic Journal (2012), 236; Waddams Price and Zhu, "Pricing in the UK Retail Energy market, 2005-2013", CCP Working Paper 1312 (2013) available at <http://competitionpolicy.ac.uk/documents/107435/107587/1312+Waddams+and+Zhu+(Final).pdf/6d49a6ed-b489-4603-a19e-890f6a098acc> (last visit 10 October 2017).

13 See "How Would the Tory Energy Price Cap Work?" 9 May 2017, available at <http://www.bbc.co.uk/news/business-39694183> (last visit 10 October 2017).

14 Helm (2016), "Regulatory Credibility and the Irresistible Urge to Meddle", available at <http://www.dieterhelm.co.uk/regulation/regulation/regulatory-credibility-and-the-irresistible-urge-tomeddle/> (last visit 10 October 2017).
} 
("SGEI"). ${ }^{15}$ An important caveat is that, in doing so, the article focuses on the reasonableness only of the retail energy component of the bill. ${ }^{16}$ This consists of the final energy price and retail mark-ups.

The conceptual framework put forward offers two shades of reasonableness that sit at the confluence of two distinct, yet related objectives of the EU energy acquis: the competition objective and the underlying principle of economic efficiency on the one hand, and that of 'high standards' of public service and consumer protection (especially for vulnerable customers) informed by the principle of social solidarity. The first objective gives rise to an economic understanding of reasonableness, whereby a reasonable price is linked directly with the benefits of competition. In this context, it is almost synonymous with the economic concept of an efficient price. The second one gives rise to a broader understanding of reasonableness that encompasses non-economic and non-competition law considerations. Unlike the first shade of reasonableness, it necessitates state intervention so as to further a broader range of regulatory objectives that lie beyond the realm of competition policy and are not in principle achieved by competitive markets. In this context reasonableness hinges on the notion of an affordable price. $^{17}$

The article elaborates carefully on these two distinct "logics" that govern price reasonableness, their different set of conditions and criteria against which they are judged and it explains how these have informed various instruments enshrined in the energy liberalisation directives for achieving reasonable prices for end-consumers. These range from consumer empowerment measures to more direct consumer protection measures informed by affordability concerns, such as retail price regulation, subsidies and tax exemptions. After providing a taxonomy of the latter instruments, it then examines their respective advantages and disadvantages by focusing on how these are perceived by the EU framework; all being imperfect options. This exercise generates some valuable

\footnotetext{
${ }^{15}$ The supply of energy has been listed as a SGEI. See Case C-393/92, Municipality of Almelo and Others, EU:C:1994:171, paras. 46-48 and Case C-159/94, Commission v France, EU:C:1997:501, para. 57.

${ }^{16}$ There are three essential components which contribute to the end-user price: i) the energy component; ii) the network component and iii) the taxes and levies component. The energy component that concerns us here, consists of the wholesale element of prices, which normally reflects the costs incurred by companies in delivering energy to the grid and the retail element of prices that covers costs related to the supply of energy to final consumers (e.g. sales, billing, meter-reading).

${ }^{17}$ Recitals 26 and 27 of Electricity Directive 2009/72/EC.
} 
insights into the way the EU framework accommodates the disparate domestic regulation within the internal energy market and the concomitant tension between the two shades of price reasonableness. It will be shown that in doing so it is guided by the overarching normative principle of "market participation", first laid down by the ECJ in the Federutility ruling, ${ }^{18}$ which has far-reaching implications for the nature, scope and limits of state intervention in national energy markets.

By drawing links between existing scholarship in the fields of energy law, competition law and consumer law and borrowing insights from economics, the article departs from a mere positive analysis of the conditions of retail price regulation and various other consumer protection measures to ensure reasonable prices, that has, with a few exceptions, ${ }^{19}$ dominated the limited scholarship in the area. ${ }^{20}$ The comprehensive and original conceptual framework offered instead serves to better inform both the positive and normative dimensions of the quest for reasonable prices in the EU.

The article is structured as follows. Section 2 discusses the economic understandings of reasonableness informed by the objective of market competition. Section 3 explores the non-economic and non-competition law understandings of reasonableness informed by considerations of social solidarity and the ECJ's "market participation" guiding principle. Section 4 examines how the latter, broader understanding of reasonableness has informed the EU's "affordability" instruments and offers taxonomy thereof. Section 5 examines the respective advantages and disadvantages of all instruments for delivering reasonable prices in all its various dimensions, as these are perceived by the EU framework. Finally, Section 6 offers some concluding observations.

\footnotetext{
${ }^{18}$ See e.g. Case C-265/08, Federutility et al v Autorita per l'energia elettrica e il gas, EU:C:2010:205, paras. $18-19$.

${ }^{19}$ Pront-van Bommel, “A Reasonable Price for Electricity” 39 J. Consum. Policy (2016) 141-158.

${ }^{20}$ See Fischerauer and Johnston, "State Regulation of Retail Energy Prices: An Anachronism in the Liberalized EU Energy Market" 9 JWELB (2016), 458-474, Bartl, "The Affordability of Energy: How Much Protection for the Vulnerable Consumers?” 33 J. Consum. Policy (2010) 225-245.
} 


\section{Economic understandings of reasonableness}

The economic understanding of a reasonable retail energy price derives from the neoclassical economics ${ }^{21}$ paradigm of a competitive market, according to which all market actors (producers and consumers) act in a rationally manner that enables them to maximize their utility or profit. The primary goal of a competitive market is to provide an efficient allocation of resources. As will be explained below, according to the economic understanding, a reasonableness of a given retail price is judged against the benchmark of a competitive market price.

The economic understanding of reasonableness is relevant to our purposes here because the competitive market paradigm features prominently in the energy liberalization directives. Specifically, Article 3(1) of the Electricity Directive 2009/72/EC ${ }^{22}$ and the Gas Directive 2009/73/EC ${ }^{23}$ states that energy undertakings must be operated with a view to achieving a "competitive market". In the same vein, the ECJ has consistently held that the principle presumption of the rules on the internal energy market is the development and maintenance of competitive markets. ${ }^{24}$ The significance of the free operation of the market mechanism has been widely embraced by the EU Courts, which have highlighted that the EU energy acquis entails "the freedom to determine the price for the supply of electricity". ${ }^{25}$ This in turn gives rise to the fundamental principle of market-based retail energy price formation. In other words, the price for the supply of energy should be first and foremost the result of market forces and not one set by the State-the market forces being policed via the ex post application of competition law.

Within the context of neoclassical economics, there can be said to be two overarching objectives of a competitive market. The first is that of maximizing economic efficiency through ensuring that goods are allocated to those who are willing to pay the most for

\footnotetext{
${ }^{21}$ Neoclassical economics applies the tools of welfare economics to a benchmark based on perfect competition. It assumes, inter alia, many buyers and sellers none of which enjoys market power. This approach takes cost and demand curves as given and focuses on equilibrium where price equals marginal cost. See e.g. Mankiw \& Taylor, Economics (3rd ed, Thomson Learning, 2014), ch. 3.

${ }^{22}$ O.J. 2009, L 211/55.

${ }^{23}$ O.J. 2003, L 211/94.

${ }^{24}$ See e.g. Case C-265/08, Federutility et al v Autorita per l'energia elettrica e il gas, EU:C:2010:205, paras. $18-19$.

${ }_{25}$ See e.g. Case C-242/10, ENEL Produzione SpA v Autorita per l'energia elettrica e il gas, EU:C:2011:861, para. 42.
} 
them (allocative efficiency) and that goods are produced at the lowest possible cost (productive efficiency). The second is that of maximizing consumer choice through encouraging the entry into the market of competing suppliers. Both are reflected in the electricity and gas directives. Recital 1 to both directives recalls that the internal energy market aims to deliver "real choice" for all consumers and achieve "competitive prices". This is further enunciated in Article 12 and Article 33(1)(c) of both directives as well as Recital 3, which provides that all customers must be enabled to buy energy from the supplier of their choice and all suppliers should be free to deliver to their customers (“eligible customers"). Moreover, Member States are required to stimulate competition by creating an environment conducive for market entry.

But it is worth pausing for a second and reflecting on what competition entails and its implications for determining whether a given price is a reasonable price. Taking a static perspective of competition, the free operation of the price formation mechanism is of vital importance to the effective and efficient functioning of competitive markets. Prices should be determined by the interaction of levels of supply (producers) and demand (consumers) in a market. The price determines what is produced and who is willing to pay for it, and vice versa. In such a context, prices provide incentives to both consumers and producers. Lower prices discourage production, but encourage consumption by consumers. High prices, on the other hand, encourage more production of a good or service, but also force consumers to reflect on their willingness to pay for a good or service that in turn reduces consumption. The good or service is therefore being allocated to those consumers who value it the most, as measured by their willingness to pay for it. These different signalling effects that the price formation mechanism generates push the price to balance the forces of consumption and production - what economist call an "equilibrium", where price equals marginal cost.

The operation of the supply and demand mechanism, besides being the natural consequence of economic forces, provides the most efficient economic outcome possible, in the sense that satisfaction for society (total surplus) is maximized at minimum cost. According to the textbook understanding of the operation of competitive markets, a reasonable price is an efficient price. In such setting, the price is equal to cost including a 
normal profit or return on capital employed, for the last unit produced. ${ }^{26}$ Hence, according to an economic logic, the reasonableness of a supplier's price in a competitive energy market would be judged by examining the relationship between the retail price and the actual cost of the product and whether this gives rises to excessive profits against the benchmark of the efficient (competitive market) price. ${ }^{27}$ In the case of retail energy supply, that concerns us here, the costs that suppliers can directly control are their operating costs (e.g. sales costs, billing costs, meter-reading costs, central service costs) and retail mark-ups, the so-called energy component of the bill. Margins are realized by covering the various costs suppliers face in supplying gas and electricity to achieve a surplus. This is their pre-tax margin out of which suppliers make their profit. Accordingly, this is the only component over which customers can exert some discipline by switching supplier. By contrast, suppliers have limited control over network transmission and distribution costs that remains closely regulated by the EU energy acquis. ${ }^{28}$ Suppliers have also limited control regarding wholesale costs that are principally determined by global commodity prices, though they do hedge gas and electricity which may result in them incurring costs which turn out to be either above or below the market price at the time of delivery. Finally, suppliers have limited control over the various social and environmental $\operatorname{costs}^{29}$ they incur in response to discharging government-led initiatives that are to be recovered through consumer bills. Hence, when considering price reasonableness according to purely economic considerations there are both direct and indirect costs facing suppliers to be taken into account.

According to the economic logic of price reasonableness, several other conditions must exist both on the supply side of the market and the demand side so as market forces

\footnotetext{
${ }^{26}$ For an analysis see Littlechild, "The CMA's Analysis of the Retail Energy Market: An Examination Using Textbook Economics", Energy Policy Research Group (Cambridge, 2017) available at: <http://www.eprg.group.cam.ac.uk/wp-content/uploads/2017/03/1703-Text_1.pdf> (last accessed 10 October 2017), pp.4-6.

${ }^{27}$ Ibid.

${ }^{28}$ See e.g. Art. 32 of Electricity Directive 2009/72/EC and Gas Directive 2009/73/EC concerning the regulation of network tariffs.

${ }^{29}$ In the UK context, government environmental programmes designed to give energy companies targets for reducing carbon emissions are administered by the regulator, Ofgem. These include the Energy Company Obligation (ECO) for promoting energy efficiency of domestic households, the Renewables Obligation, for promoting large-scale renewable electricity projects, and Feed-in Tariffs that support the switch from oil and gas fired heating systems to sustainable sources of energy. See https://www.ofgem.gov.uk/ofgem-publications/64006/householdenergybillsexplainedudjuly2013web-pdf (last accessed 10 October 2017).
} 
to produce reasonable retail prices. First, there should be sufficient incentives for productive efficiency and innovation. Second, the natural monopoly markets for transmission and distribution should be properly regulated and sufficiently separated (unbundled) from the competitive markets of generation and supply so as to prevent cross-subsidy and market manipulation. ${ }^{30}$ Third, there must be a credible threat of losing customers via switching or a credible threat of market entry that will erode profits. Finally, for the threat to be credible there need to be low barriers to entry and wellinformed, empowered consumers able to engage with the market and switch to more efficient suppliers. In fact, active consumer participation in the market is the ultimate factor for reasonable prices to be realised, according to the economic understanding. This is because lack of consumer engagement with the energy market can give suppliers a position of unilateral market power concerning the inactive body of customers, which are then able to exploit through pricing practices, as the recent investigation by the UK Competition and Markets Authority ("CMA") into the UK retail energy market illustrated. ${ }^{31}$

In fact, consumer empowerment measures, that aim to enable consumer participation in the market so as to stimulate competition between energy suppliers, feature now more prominently in the EU energy acquis, ${ }^{32}$ as well as in the broader EU policy discourse. ${ }^{33}$ Crucially, the Third Energy Package prioritizes, as will become apparent in the following sections, consumer empowerment, ${ }^{34}$ rather than direct consumer protection measures, such as retail price regulation, so as to bring about reasonable prices. In doing so, it has also taken on board behavioural insights into consumer behaviour in energy markets,

\footnotetext{
${ }^{30}$ See Ch. IV, Electricity Directive 2009/72/EC and Ch. III, Gas Directive 2009/73/EC and Regulation (EU) 1227/2011 of the European Parliament and of the Council of 25 October 2011 on wholesale energy market integrity and transparency, O.J. 2011, L 326/1.

31 CMA (2016), "Energy Market Investigation: Final Report", available at: file:///Users/denimantzari/Desktop/final-report-energy-market-investigation.pdf (last accessed 10 October 2017), para. 9.283.

${ }^{32}$ See $\operatorname{COM}(2015)$, "A Framework Strategy for a Resilient Energy Union with a Forward-Looking Climate Change Policy" (25 February 2015), at 11. COM(2015), "Energy Union Package - Roadmap for the Energy Union", at 3; $\operatorname{COM}(2015)$, "Delivering a New Deal for Energy Consumers" (15 July 2015).

${ }^{33}$ COM(2007), "EU Consumer Policy Strategy 2007-2013", at 5; COM(2011), "Single Market Act-Twelve Levers to Boost Growth and Strengthen Confidence", para. 2.4.

${ }^{34}$ See Annex 1 of the Electricity Directive 2009/72/EC and Gas Directive 2009/73/EC. For an analysis see Johnston, "Seeking the EU 'Consumer' in Services of General Economic Interest" in Leczykiewicz and Weatherill (Eds.), The Images of the Consumer in EU Law: Legislation, Free Movement and Competition Law (Hart, 2016).
} 
which demonstrate that even if switching opportunities exist consumers are far from rational. ${ }^{35}$ For example, empirical research suggests that consumers tend to have a preference for the status quo. ${ }^{36}$ Such behaviour, otherwise known as "status quo bias", is brought up to explain situations whereby consumers fail to investigate alternative energy contracts that may be more beneficial to them. Hence, Member States are required to put in place arrangements to ensure that consumers are assisted through the provision of clear and user-friendly information about their rights, especially the right to switch supplier, the content of the supply contracts and their energy consumption. Regarding the latter, smart meters are in the process of being rolled out for more accurate metering that combined with price comparison tools can facilitate switching, ${ }^{37}$ although their cost to the energy consumer should not be underestimated. ${ }^{38} \mathrm{We}$ shall return to this point later, as the ability of consumers to participate in the retail energy market has served, as we shall see, as an overarching normative principle for mediating between the two shades of reasonableness.

Having elaborated on the main preconditions and conditions governing price reasonableness from an economic standpoint, the following section will explain how the latter shade of reasonableness differs from the broader understanding of reasonableness informed by considerations of social solidarity.

\section{Beyond economic reasonableness: Reasonableness as affordability}

At the opposite end of the economic logic of price reasonableness, lays a broader understanding of reasonableness informed by non-economic and non-competition law considerations. Whereas the economic understanding of price reasonableness is informed by the principle of economic efficiency, the broader understanding of reasonableness, that

\footnotetext{
${ }^{35}$ See Mc Fadden, "Free Markets and Fettered Consumers" 96(1) Am. Econ. Rev. (2006) 3-29; Waddams Price and Zhu, "Empirical Evidence of Consumer Response in Regulated Markets" 12(1) JCL\&Econ. (2016) 113-149; Lavrijssen, op. cit. supra note 7.

${ }^{36}$ Pollitt and Shaorshadze, "The Role of Behavioral Economics in Energy and Climate Policy", ESRC Electricity Policy Research Group (Cambridge, 2011).

${ }^{37}$ New Deal for Energy Consumers, op. cit. supra note 32, at 3-5.

${ }^{38}$ European Commission (Joint Research Centre), "Smart Metering Deployment in the European Union", available at: 〈http://ses.jrc.ec.europa.eu/smart-metering-deployment-european-union> (last accessed 10 October 2017).
} 
concerns us here, is informed by considerations of social solidarity. ${ }^{39}$ In this context reasonableness hinges on the notion of affordability. Affordability is referred to in the EU energy acquis as one of the defining elements of services of general economic interest (along with those of continuity, universality, equality and transparency), whereas "high levels of affordability" feature also in the new Protocol No 26 on Services of General Interest (inserted by the Treaty of Lisbon) among the "shared values of the Union" in respect of services of general interest. ${ }^{40}$ However, the concept is nowhere defined as such in the EU acquis.

Turning to the literature, it is frequently referred to as the ability of consumers to pay for a minimum level of a certain service. ${ }^{41}$ At the heart of the issue lies the distinction between "willingness to pay" and "ability to pay". The latter is observed through an analysis of the size of energy bills and the proportion of overall spending as part of income, while the former is best assessed through an analysis of the "willingness to pay" (usually through dedicated consumer surveys). That is the maximum amount a consumer is willing to pay for energy - a proxy for how much the consumer values the good. Within the context of an optimal allocation of resources, those who would value most the good should be assigned to it. However, consumers who are willing to pay the equilibrium price may not afford the good at such a price. What is more, because average cost per unit declines as consumption rises, those poorer consumers may be paying more as a proportion of household income than wealthy ones who consume greater quantities. Thus, their ability to pay prevents them from taking decisions according to their willingness to pay.

Though affordability can be achieved via various instruments, as the following section will illustrate, the common denominator is that they all involve a departure from the

\footnotetext{
${ }^{39}$ For a general account see Barnard, "EU Citizenship and the Principle of Solidarity" in Dougan and Spaventa (Eds.), Social Welfare and EU Law (OUP, 2005), p. 157. See further Prosser, "Regulation and Social Solidarity" 33(3) J. Law and Soc. (2006) 364-387 and Szyszczak, "Public Service Provision in Competitive Markets" 20(1) YEL (2001) 35-77.

${ }^{40}$ Protocol No 26 on Services of General Interest, Art. 1.

${ }^{41}$ To this effect see UK Regulators Network, "Understanding Affordability Pressures in Essential Services" (20 January 2015) available at: <http://www.ukrn.org.uk/wpcontent/uploads/2016/07/2015JanUnderstandingAffPressuresInEssSer.pdf> (last visit 10 October 2017). See further Fankhauser and Tepic, "Can poor consumers pay for energy and water? An affordability analysis for transition countries" EBRD Working Paper (May 2005) available at: $<$ http://www.ebrd.com/downloads/research/economics/workingpapers/wp0092.pdf $>$ (last visit 10 October 2017).
} 
purely economic rationales for public intervention in markets, summarized in the concept of 'market failure', so as to achieve a socially, rather than economically desirable outcome. Such outcome is reflected in the concept of an "affordable price". Hence, affordability should not be conflated with the outcome of a competitive market, as misguidedly been stated. ${ }^{42}$ On the contrary, affordability necessitates, in principle, a departure from cost-reflective prices set by the market mechanism.

Considerations of social solidarity become relevant to our understanding of reasonableness as affordability because of the nature of the service being offered. The provision of energy supply in a given society is crucial in realizing its territorial cohesion and stability. Energy undertakings carry out activities, which are essential for the functioning of the society and on which many other activities depend. There are also important for social cohesion, as being cut off from electricity would amount to social exclusion. Hence, social solidarity considerations, in the form of social and territorial cohesion, underpin our understanding of reasonableness as affordability.

Social solidarity is reflected in the Preamble to the EU Charter of Fundamental Rights as one of the founding values of the "ever closer Union" and in Chapter IV. It further informs the EU energy acquis objective of ensuring "high standards of universal and public service" and the protection of "final consumer", especially the "vulnerable" one, in the context of liberalized energy markets, from which stem various instruments for pursuing affordability. To better appreciate its normative connotations, one should dig into the intellectual roots of the concept, which are to be found in the French legal concept of service public ${ }^{43}$ (public service) that has in turn profoundly influenced the EU's approach towards services of general economic interest. As developed by the French public law scholar Léon Duguit, the concept of service public prescribed that any type of state intervention into society could only be legitimized by its function "to protect the necessary preconditions for social interdependence and interaction"" ${ }^{44}$ i.e. to serve the needs of society (service public). In light of this conceptualization, the notion of

\footnotetext{
${ }^{42}$ See Bartl, op. cit. supra note 20, at 228.

${ }^{43}$ Schweitzer, "Services of General Economic Interest: European Law's Impact on the Role of Markets and of Member States" in Cremona (Ed.), Market Integration and Public Services in the European Union (OUP, 2011), pp. 11-62.

${ }^{44}$ Duguit, Traité de droit constitutionnel, tome II (1928) \} 8, 61 and 70-1 in: Schweitzer op. cit supra note 43, p. 13.
} 
service public represents the state's commitment to social solidarity and prescribes the basis and limits of state action. However, as Heike Schweitzer discusses, the meaning of the service public eventually shifted over time within the French École de service public from representing the basis and limits of state's legitimacy to actually making the public interest the binding goal of the state, leading to an expansion of state's activities. "[T]he state is defined by its task to represent the public interest; but defining the public interest is within the free discretion of the state." ${ }^{25}$

Understanding the notion of social solidarity as it finds its expression in the continental legal concept of service public is crucial for our purposes here as it underpins the main instruments of consumer protection enshrined in Article 3(1) of the energy liberalization directives 2009/72/EC and 2009/73/EC, that of Universal Service Obligations (USOs) and Public Service Obligations (PSOs). Each will be examined in turn.

USOs intend to guarantee the supply of electricity at "reasonable prices" to those who cannot afford it at the market price. ${ }^{46}$ They, hence, represent the broader concept of price reasonableness underpinned by social solidarity, as they depart from cost-reflective pricing prescribed by the economic understanding of reasonableness, to allow for redistributive pricing. ${ }^{47}$ Redistributive pricing is achieved by imposing on one or more firms an obligation to supply energy to all consumers on a non-discriminatory basis, i.e. regardless of any variations in the cost of supplying different groups. Distribution is directed to high-cost service customers who, if market forces alone operated, they would simply not be served as it would be uneconomic to do so, let alone offered an affordable price. Hence USOs intends to socialize the costs of energy supply that in the era of stateowned monopolies were addressed through cross subsidization. Although in principle economic efficiency considerations might exist for imposing USOs, ${ }^{48}$ in practice their imposition relates to non-efficiency objectives such as social solidarity and the desire to prevent social exclusion.

\footnotetext{
${ }^{45}$ Schweitzer op. cit. supra note 43.

${ }^{46}$ See Micklitz, "Universal Services: Nucleus for a Social European Private Law" in Cremona (Ed.), Market Integration and Public Services in the European Union, (OUP, 2011), ch 3.

${ }^{47}$ For an economic perspective see Cremer et al, "Universal Service: An Economic Perspective", 72 Annals of Public and Cooperative Economics (2001) 5-43, p. 14.

${ }^{48}$ In the case of telecoms, for example, where USO can be a remedy for a network externality.
} 
USOs should not be conflated with PSOs. ${ }^{49}$ The latter are broader in their scope and may involve not only USOs, but also security of supply and environmental objectives and, most relevant for our purposes here, price regulation. As affordable energy supplies are essential to end-uses, the directives allow Member States to depart from the constitutional imperative of "open and undistorted competition" upon which the internal market is premised, and impose PSOs on undertakings operating in the energy sector with respect to inter alia the price of electricity supply. ${ }^{50}$ Such PSOs stem from the fact that energy supply constitutes a service of general economic interest, a rather elusive and constantly evolving EU concept, ${ }^{51}$ on the basis of which Member States can by virtue of Article 106(2) TFEU, derogate from the Treaty rules, in particular those on competition, so as to address the impact of liberalization on consumers. Such obligations must be clearly defined, transparent, non-discriminatory and guarantee equality of access for undertakings to national customers. ${ }^{52}$ On the basis of this provision, Member States have sought to regulate retail energy prices so as to address "unreasonable prices" generated by the market mechanism, although in practice justifying this intervention proves to be difficult due to the ECJ's insistence on construing it narrowly, as we shall see below. This implies that Article 3(2) should be interpreted against the background of Article 106(2) TFEU and the corresponding case law of the ECJ, including the Court's application of the proportionality requirement. ${ }^{53}$ The requirement of proportionality has always been the most contentious, as it involves a delicate balance between market and non-market considerations, which in itself raises normative questions about the

\footnotetext{
${ }^{49}$ See Sauter, Public Services in EU Law 15 (CUP 2015), p.15

${ }^{50}$ Article 3(2) Electricity Directive 2009/72/EC. The Gas Directive 2009/73/EC does not provide for such a price-related obligation, but mentions in Recital 47 that EU citizens and small enterprises should be able to enjoy public service obligations, in particular with regard to reasonable tariffs.

${ }^{51}$ See for example, $\operatorname{COM}(2003)$, "Green Paper on Services of General Interest"; "Communication from the Commission on the application of the European Union state Aid rules to compensation granted for the provision of services of general economic interest" O.J. C. 8/4, para. 45. See further Lenaerts, 'Defining the Concept of "Services of General Interest" in light of the "Checks and Balances" Set Out in the EU Treaties', 19(4) Jurisprudence (2012) 1247-1267; Sauter, "Services of General Economic Interest and Universal Service in EU Law" 33 E. L. Rev. (April 2008) 167-193.

${ }^{52}$ See Art. 3(2) of Electricity Directive 2009/72 EC and Gas Directive 2009/73/EC.

${ }^{53}$ See Deruytter \& Vandendriessche, "State Regulation of Supply Prices for Electricity and Gas: The Federutility Case", in: Roggenkamp and Hammer (Eds.), European Energy Law Report IX, (Intersentia, 2012), p. 35.
} 
institutional capability and legitimacy of the judiciary to undertake such task. ${ }^{54}$ This is not the place to explore the ECJ's long line of case law on the proportionality requirement. ${ }^{55}$ Suffice it to say-for present purposes, that while on the basis of Article 14 TFEU and Article 4 (2) TEU, Member States enjoy a broad discretion in defining and organizing their SGEI by virtue of their proximity to citizens (soft version of proportionality), ${ }^{56}$ this margin is significantly narrowed, whenever sector-specific legislation incorporating SGEI is enacted at the EU level (strict proportionality of the least restrictive alternative). ${ }^{57}$ It is thus the latter, stricter, form of proportionality that is relevant to our analysis.

However, experience of the energy sector suggests that EU Member States have considerable freedom to determine the scope and contents of public service obligations and are allowed to take national circumstances and policy objectives into account. ${ }^{58}$ In fact, because of the poor clarification of the concept of PSO at the EU level and the lack of EU competence to design social policy in the field of energy, let alone a clear basis for energy until the Treaty of Lisbon, ${ }^{59}$ Member States have been acting as gap-fillers in the EU policy, defining national solutions to counteract the impact of liberalization. The permissive approach is, however, subject to a strict degree of supervision by the European Commission for the possible effects of the measures on national competition. It is also complemented by the duty of the NRAs to monitor the level and effectiveness of market opening and competition at the retail level, including prices for household customers. $^{60}$

The Directives, however, remain silent as to the rationae personae of PSOs relating to the price of supply. For example, can large energy suppliers benefit from such

\footnotetext{
${ }^{54}$ See Cruz, "Beyond Competition: Services of General Interest and European Community Law" in de Búrca (Ed.), EU Law and the Welfare State: In Search of Solidarity (OUP, 2005), ch.6.

${ }^{55}$ See e.g. Case 155/73, Sacchi, EU:C:1974:40, paras. 14-18; Case 66/86, Ahmed Saeed Flugreisen and Others $v$ Zentrale sur Bekampfung unlauteren Wettbewerbs, EU:C:1989:140, paras. 55-58; C-41/90, Klaus Höfner and Fritz Elser v Macrotron GmbH, EU:C:1991:161, para. 25; Case C-320/91, Corbeau, EU:C:1993:198; Case C-393/92, Almelo, EU:C:1994:171; Case C-157/94, Commission v Netherlands EU:C:1997:499. See further Cruz, op. cit. supra note 54.

${ }^{56}$ See e.g. Case C-320/91, Corbeau.

${ }^{57}$ See Cruz, op. cit. supra note 54.

${ }^{58}$ Hancher and Larouche, "The Coming Age of EU Regulation of Network Industries and Services of General Economic Interest" in Craig and De Burca (Eds.), The Evolution of EU Law (OUP, 2011), p. 777.

${ }^{59}$ Art. 194 TFEU.

${ }^{60}$ See Art. 37 of the Electricity Directive 2009/72/EC and Art 41 of the Gas Directive 2009/73/EC, respectively.
} 
regulation? Does reasonableness as affordability apply to them? Or is it the narrow logic of economic reasonableness applicable in this case? To this effect, the ECJ has played an important role, not only in mediating between the two shades of reasonableness, but also in providing an overall normative principle guiding the Member States' choices as to when and how to depart from economic reasonableness. The normative principle is captured in the so-called "market participation" test implicitly adopted by the Court. In other words, the ECJ's approach is predicated upon an assessment of the consumers' ability to participate in the retail energy market and act as empowered consumers able to search, assess and act upon the information presented to them so as to attract better deals. While initially introduced with the aim of regulating the discretion Member States enjoy when determining the scope and content of PSOs, in practice the "market participation test" as regulated by the principle of proportionality, has far-reaching implications that extend beyond merely prescribing the conditions of retail price regulation. Properly understood, it provides yet another intellectual foundation, along with that of social solidarity, for moving beyond the narrow conception of price reasonableness. If active consumer participation in the market is the ultimate factor for reasonable prices to be realised, according to the economic approach, limited ability to participate in the market provides a normative rationale for embracing the broader logic of price reasonableness. The following subsection will explore in greater detail the "market participation" test before delving further into its implications in Section 5 .

\subsection{Moving beyond economic price reasonableness: The ECJ's "market participation test"}

The "market participation" test was first laid down in the Federutility ruling, where the CJEU was presented with the opportunity to consider the legality of retail price regulation under the energy liberalisation directives. ${ }^{61}$ The Court paid specific attention to the rationae personae of the measures and advanced a context-sensitive test that encompasses pragmatic considerations of the ability of consumers to achieve fair prices through the market mechanism. The ruling concerned an Italian law adopted few days before 1 July 2007, when full libersalisation was supposed to take place, which allocated

\footnotetext{
${ }^{61}$ Case C-265/08, Federutility.
} 
to the regulator (Autorità per l'energia elettrica e il gas) the power to define "reference prices" that the distributors or suppliers of gas within the scope of their PSOs were bound to incorporate in their commercial offers to final customers. These de facto binding prices were set at levels below market prices. The purpose of this rule was to protect the final consumers of gas against excessive prices and, therefore to guarantee their right to a universal service, including reasonable and affordable energy prices. The applicants argued that the regulation of gas prices violated the then Gas Directive 2003/55/EC. ${ }^{62}$ The national court in its preliminary reference asked whether maintaining in effect the power of the NRA to set reference prices is contrary to the EU law or whether it could be allowed due to particular circumstances of the market, still characterized by an absence of 'effective competition'.

At the outset, the ECJ pointed out that Article 3(2) of the Gas Directive enables the Member States to accommodate two competing interests. On the one hand, it seeks to promote the Directive's objective of establishing a "competitive market in natural gas". On the other hand, it seeks to reassure the Member States that liberalization will not be to the detriment of consumers. Accordingly, when having recourse to Article 3(2), NRAs must strive to accommodate these two competing interests. Then the Court laid down some detailed guidance as to how that balance had to be struck, in the sense of the way the principle of proportionality should be applied, so as to ensure retail energy price regulation complies with the Directive.

First, the intervention should be justified in the general economic interest. ${ }^{63}$ The Court held that the then Directive 2003/55 EC allowed Member States to assess whether and in the general economic interest it was necessary to impose PSOs upon undertakings operating in the gas sector. Second, Member States should comply with the principle of proportionality. ${ }^{64}$ In essence, proportionality entails that the intervention should not to go beyond what is necessary to achieve the objective that is being pursued in the general economic interest and should be limited to the price component influenced by the specific circumstances, but not to the final end-users' price. ${ }^{65}$ Furthermore, the intervention

\footnotetext{
62 O.J.2003, L176/57.

${ }^{63}$ Case C-265/08, Federutility, para. 25

${ }^{64}$ Ibid, paras, 35; 38; 43.

65 Ibid., para.38.
} 
should be transitory in nature with limited duration and subject to periodic reexamination at close intervals by the relevant regulatory authority. Thirdly, the ECJ stated that the "requirement of proportionality must also be assessed with regard to the scope ratione personae of the measures and more particularly its beneficiaries" ${ }^{66}$ In other words, when assessing whether a specific national measure is proportionate, account has to be taken of differences between the position of undertakings and the position of household consumers and also of objective differences in size between the undertakings themselves. ${ }^{67}$ In contrast to Advocate General Colomer, ${ }^{68}$ the ECJ held that the Gas Directive does not in principle exclude the possibility that the undertakings irrespective of their size as final consumers of gas benefit from the PSOs which Member States may adopt in the context of Article 3(2) of that Directive, but they should not benefit in an identical manner as household and small enterprises. ${ }^{69}$ Hence, price measures will generally need to make a distinction between households and undertakings as energy consumers, otherwise identical treatment of different categories of consumers has to be justified. Finally intervention should comply with the criteria set out under Article 3(2) of the Directive, namely that the PSOs must be "clearly defined, transparent, nondiscriminatory and verifiable", as well as guaranteeing equal access for companies to consumers. ${ }^{70}$

The Federutility principles were confirmed in the Enel case, ${ }^{71}$ which involved a decision by the Italian regulatory authorities to regulate certain electricity generating installations that could be designated essential for the provision of dispatching and balancing services. The legislation imposed upon those undertakings the obligation to submit bids on the national electricity markets in accordance with the limits and criteria laid down by the electricity transmission and distribution system operator. The latter prevented undertakings from freely determining the remuneration for such bids. The ECJ examined the national rules in question and in particular the conditions under which Member States may intervene by imposing PSOs - in this case, for guaranteeing the

\footnotetext{
${ }^{66}$ Ibid., para.39.

${ }^{67}$ Ibid., para. 42.

${ }^{68}$ Opinion of A.G. Colomer in C-265/08, Federutility, EU:C:2009:640.

${ }^{69}$ Case C-265/08, Federutility, para. 41 and 43.

${ }^{70}$ Ibid., para. 47.

${ }^{71}$ Case C-242/10, Enel Produzione SpA v Autorità per l'energia elettrica e il gas, EU:C:2011:861.
} 
reliability of the system and for protecting consumers - drawing upon and confirming the Federutility principle that the EU energy acquis entailed "the freedom to determine the price for the supply of electricity". ${ }^{72}$ It then applied the conditions for imposing PSOs, in a way largely comparable to that in the Federutility case. The main difference between the Enel and the Federutility case relates to the Court's application of the proportionality principle, as it included an explicit testing of whether the measure was suitable, taking into account the specific features of the electricity market, including inflexible demand for a product that cannot be stored. ${ }^{73}$

Similarly, in Commission $v$ Poland, ${ }^{74}$ in an infringement decision against Poland concerning an obligation imposed on all energy undertakings to submit to the President of the Energy Regulation Agency for prior approval the supply tariffs for gas, the ECJ found fault with the proportionality principle, as the scope rationae personae was found too broad in its coverage. No explanation was given as to why different types of customer groups ought to be treated similarly with regard to benefiting from regulated prices. Specifically, the Court emphasized that no distinction was made between final industrial customers and traders within the category of non-household residential clients. Furthermore, the duration of the scheme seemed permanent, rather than subject to regular review.

Finally, in Anode ${ }^{75}$ the Court made clear that the French Conseil d'Etat would have to assess whether the limitation of retail price regulation to households and small and medium-sized enterprises was proportionate to the security of supply and territorial cohesion objectives claimed by the French Government. The Court again referred to the lack of time limits for the duration of the regulated prices, the need to focus on the relevant cost component that would affect supply security/and or territorial cohesion and the need to justify the scope ratione personae of the measure, which covered smaller business and households. ${ }^{76}$

\footnotetext{
72 Ibid., para 42.

73 Ibid., para. 57.

${ }^{74}$ Case C-36/14, Commission v Poland, EU:C:2015:570.

${ }^{75}$ Case C-121/15, Association nationale des opérateurs détaillants en énergie (ANODE) v Premier ministre and Others, EU:C:2016:248.

${ }^{76}$ Ibid., para. 41.
} 
In all the above cases, while the ECJ did not elaborate on the reasons why the situation of industrial undertakings differs from that of household consumers, when delineating the scope rationae personae of the PSOs, it is evident that their ability to participate in the market played a crucial role. ${ }^{77}$ Hence, measures that fail to differentiate among the different categories of customers cannot be considered a proportionate restriction of the principle of market-formed retail energy prices.

\section{Pursuing affordability: A taxonomy of the different instruments}

The foregoing discussion explored the two distinct "logics" of reasonableness that inform the concept of "reasonable price for energy supply" and elaborated on their underlying principles, conditions and criteria according to which they should be judged. It also brought to the fore that two alternative mechanisms exist for pursuing reasonable prices, that of competition and its corollary of consumer empowerment and that of state intervention in the form of consumer protection measures. Understanding reasonableness as affordability also allowed us to draw some preliminary observations on the relevance and conditions of state intervention in retail energy markets, as prescribed by first, the concept of service public and the conceptual frameworks of USOs and PSOs deriving thereof and second, by the ECJ's "market participation" test.

The purpose of this section is to further explore how the broader understanding of reasonableness translates into different affordability instruments enshrined in the EU energy acquis and offer a taxonomy thereof. It will be shown that the pursuit of reasonableness as affordability is far more complex than one may have anticipated, as it presupposes an appreciation of both the different images of the energy consumer and the multifaceted nature of consumer vulnerability.

Instruments for achieving affordable prices can be distinguished according to two different criteria. First, according to whether they are implemented within the market (e.g. retail price regulation) or outside the market context (e.g. social welfare measures). Second, according to their scope rationae personae, i.e. their beneficiaries. In the latter case, they may be of a general application, if they focus on a broadly defined category of

\footnotetext{
${ }^{77}$ Fischerauer and Johnston op. cit. supra note 20, p. 469.
} 
consumers, such as household consumers or of a targeted application, if they focus on a narrowly specified category of consumers, such as vulnerable consumers. Instruments of general application include the provision of USO, expressly reserved, as we shall see below, for household consumers and retail price regulation through the imposition of PSOs relating to the price of supply, but, as we discussed in the previous section, under strict conditions of necessity and proportionality, advanced in the ECJ's "market participation" test. Instruments of targeted application seek in principle to address the needs of vulnerable consumers and may relate to price regulation in the form of social tariffs, ${ }^{78}$ direct subsidies and general social welfare measures.

It immediately becomes apparent that a proper engagement with the instruments of general application presupposes an appreciation of the various and multiple consumer 'images'. ${ }^{79}$ In the same vein, measures of targeted application necessitate an understanding of the various images of consumer vulnerability. The remainder of this section will first discuss the different images of consumers, as these derive from the energy liberalization directives, as this category-based understanding has informed the scope of measures of general application, that is retail price regulation through the imposition of USOs and PSOs. It will then examine the concept of consumer vulnerability and how its different variations inform measures of targeted application, such as social tariffs and subsidies.

\subsection{Instruments of general application: Retail price regulation through the imposition of USOs and PSOs}

Before examining the beneficiaries of retail price regulation through the imposition of USOs and PSOs as an instrument of general application, we should first appreciate the various and multiple consumer images, as these are enshrined in the liberalization directives. This is crucial, as the category-based approach to distinguishing the different faces of energy consumers adopted by the Directives has informed the scope of USOs

\footnotetext{
${ }^{78}$ Indeed, the Directives explicitly allow price regulation addressed specifically to vulnerable consumers. See Art. 3(7) of the Electricity Directive 2009/72/EC and Art. 3(3) of the Gas Directive 2009/72/EC, respectively.

${ }^{79}$ See e.g. Recitals 24-29 of Gas Directive 2009/73/EC.
} 
and PSOS. In the context of retail energy supply that concerns us here, the Directives use the term "final customer", who refers to the customer purchasing electricity for his or her own consumption, and by adopting a categorical approach they distinguish between "household customers", where special attention is paid to the so-called "vulnerable consumers", and "non-household customers", where special reference is made to "small and medium-sized enterprises" (namely enterprises with fewer than 50 occupied persons and an annual turnover or balance sheet not exceeding EUR 10 million).

State intervention in the form of USOs is expressly reserved for household customers (and where Member States deem appropriate, small enterprise ${ }^{80}$ ). The Directive 2009/72 EC furthermore provides that the PSOs, including that of universal service, and the common minimum standards that follow therefrom, need to be further strengthened to make sure that all customers, especially vulnerable ones, are able to benefit from competition and fair prices. ${ }^{81}$ It is inferred from the above, that it is unclear to what extent Member States can remove retail price regulation if they cannot fulfil the Directive's mandate to guarantee reasonable prices for all household customers and in some cases for small enterprises.

Regarding PSOs relating to the price of supply, while EU law contemplates price regulation, it imposes some rather strict conditions regarding its application, as the previous section illustrated in great deal. Most crucially for our purposes here, while PSOs qualify as a measure of general application, identical treatment of different categories of consumers, such as household customers and industrial customers, has to be justified in line with the "market participation" test. However, while the ECJ departed to an extent from the category-based approach to energy consumers found in the energy directives, by essentially acknowledging that "some consumers are more equal than others," when it comes to their engagement and participation in the market, it did not distinguish between "vulnerable" and "non-vulnerable" consumers within the category of household consumers. Distinguishing the two is crucial for implementing instruments of targeted application, to which the next subsection turns to.

\footnotetext{
${ }^{80}$ See Article 3(2) of the Electricity Directive 2009/72/EC and the Gas Directive 2009/73/EC.

${ }^{81}$ See Recital 47 and 50 to Gas Directive 2009/73/EC.
} 


\subsection{Instruments of targeted application and the multifaceted nature of consumer vulnerability}

Instruments of targeted application lie at the core of the reasonableness as affordability paradigm, as their rationae personae concerns those consumers who are vulnerable or live in energy poverty. They may involve measures implemented within the market (e.g. social tariffs) or outside the market (e.g. general social welfare measures, energy efficiency measures) The legal basis for such measures is to be found in Article 3(8) of the Electricity Directive 2009/72/EC:

Member States shall take appropriate measures, such as formulating national energy action plans, providing benefits in social security systems to ensure the necessary electricity supply to vulnerable customers, or providing for support for energy efficiency improvements, to address energy poverty where identified, including in the broader context of poverty. Such measures shall not impede the effective opening of the market set out in Article 33 or market functioning and shall be notified to the Commission, where relevant, in accordance with the provisions of paragraph 15 of this Article. Such notification may also include measures taken within the general social security system. ${ }^{82}$

In exploring the different instruments, however, it is important to appreciate first that consumer vulnerability may come in different forms and second, that it is distinct from the situation energy poverty. Indeed, it is important that the two concepts are not to be conflated, as each invites different measures so as to ensure affordable prices.

On the basis of subsidiarity, it is left to the Member States to define the concept of vulnerable customers, which may refer to "energy poverty and, inter alia, to the prohibition of disconnection of energy to such consumers in critical times" ${ }^{83}$ Member States have opted for different definitions, implicit and explicit, of the concept of vulnerable consumers. ${ }^{84}$ Implicit definitions refer to concepts of vulnerable consumers, which are an integral part of the national legislations without being put into specific wording. Other Member States have introduced an explicit definition, whereby legislation

\footnotetext{
${ }^{82}$ See also Art. 3(4) of the Gas Directive 2009/73/EC.

${ }^{83}$ See Art. 3(7) of the Electricity Directive 2009/72/EC and Article 3(3) of the Gas Directive 2009/73/EC, respectively.

${ }^{84}$ ACER/CEER, op. cit. supra note 8.
} 
clearly identifies specific segments of the population that are considered vulnerable due to their characteristics or living conditions. These commonly relate to low-income households, the elderly or people in bad health. Very few, however, take into account single parents or those in debt. In some Member States, exceptional circumstances such as unemployment are covered. ${ }^{85} \mathrm{EU}$ law respects these national definitions even if they produce divergences that may lead to market segregation.

Norbert Reich's typology of consumer vulnerability allows us to better appreciate its multifaceted nature. ${ }^{86}$ According to Reich, vulnerability comes in three different forms: i) physical disability; ii) intellectual disability and iii) economic disability. ${ }^{87}$ While physical disability is quite self-explanatory, intellectual disability is far more complex. Reich employs Griggs' definition which regards as intellectually disabled 'those persons who have limited rights and resources to exercise the range of choices possible in a given consumer market. ${ }^{98}$ Developing this definition further it may be said to refer to difficulties 'cop[ing] with the requirements of the modern consumer society' ${ }^{89}$ For example, it may relate to difficulties in gathering and processing information and gaining access to advice and support. Such barriers to consumer empowerment may make it, in turn, difficult for consumers to find energy contracts best suited to their situation, or may lead to exclusion from technological innovations, such as the development of smart meters, smart grids, and demand response programs. ${ }^{90}$ Finally, economic disability may stem from the difficult economic situation of the consumer and relate to unemployment, illness and other unforeseen circumstances. ${ }^{91}$

\footnotetext{
${ }^{85}$ See Deller and Waddams, "Affordability of Utilities' Services: Extent, Practice, Policy. Research Paper 3: Policies Used to Tackle Utility Affordability in Different Member States", (CERRE, 22 October 2015) available at < http://www.cerre.eu/sites/cerre/files/Affordability_ResearchPaper_3.pdf > p.8.

${ }^{86}$ Reich, "Vulnerable Consumers in EU Law", in Leczykiewicz and Weatherill (Eds.), The Images of the Consumer in EU Law: Legislation, Free Movement and Competition Law (Hart, 2016), p. 141.

${ }^{87}$ Ibid.

${ }^{88}$ Griggs, "The Consumer with an Intellectual Disability-Do We Respond, if so, How?, in: Reich,

"Vulnerable Consumers in EU Law" op.cit. supra note 86.

${ }^{89}$ Micklitz, op. cit. supra note 46, at p. 21.

${ }^{90}$ For an empirical assessment see Fernández- Gutiérrez et al, "Competition and Switching in Public Service Markets: Can They Reduce Inequalities?" 11(1) Journal of Regulation and Governance (2017), $41-$ 63.

${ }^{91}$ Reich, op.cit. supra note 86, at 144.
} 
These understandings are largely reflected in the Commission's interpretive note on retail markets. ${ }^{92}$ For example, it assumes that disabled consumers (or elderly consumers) could qualify as being vulnerable, thus acknowledging physical disability; but not necessarily those from these groups with high incomes. ${ }^{93}$ It further explicitly refers to "elderly consumers on an extremely low income who may be considered vulnerable during a severe winter if they use electricity to heat their homes" ${ }^{94}$ thus appreciating economic disability. Consumer vulnerability relating to intellectual disability is not referred to in the interpretive note, but it is acknowledged in the workings of the Vulnerable Consumers Working Group, an initiative launched by the Commission so as to establish a better understanding of the drivers of vulnerability and provide recommendations. ${ }^{95}$ It is the group's understanding that this type of vulnerability invites consumer awareness measures, such as the UK's 'energy best deal campaign' 96 implemented by the regulator, Ofgem, and consumer empowerment measures, such as the provision of information and improved transparency in billing practices to enable switching so that reasonable retail energy prices prevail. Price comparison tools have also increased in popularity as a means for enabling consumers to find and switch to the most appropriate tariff. In addition to individual consumers switching supplier, collective switching schemes can also be used to reduce the energy bill for groups of consumers.

Energy poverty, on the other hand, is linked to lower income only and not to social or other characteristics. It has been defined as the inability of consumers to heat their homes or enjoy other energy services at an affordable cost. ${ }^{97}$ One indicator is the expenditure on energy compared to the household income that ranges from Member State to Member State. To this effect, the Commission has calculated that the lowest income households in the EU spent approximately 9\% of their income on energy, 50\% more than what they

\footnotetext{
${ }_{92}$ Commission Staff Working Paper, "Interpretive note on Directive 2009/72/EC concerning common rules for the internal market in electricity and Directive 2009/73/EC concerning common rules for the internal market in natural gas - Retail Markets" (Brussels, 22 January 2010).

${ }^{93}$ Ibid at 4.4.

${ }^{94}$ Ibid.

${ }^{95}$ See Vulnerable Consumer Working Group Guidance Document on Vulnerable Consumers (November 2013) available at: $\langle$ https://ec.europa.eu/energy/sites/ener/files/documents/20140106_vulnerable_consumer_report_0.pdf $>$ (last accessed 10 October 2017).

${ }^{96}$ Available at https://www.ofgem.gov.uk/ofgem-publications/38138/energybestdealbookleteng2012-pdf (last accessed 10 October 2017)

${ }^{97}$ See ACER and Trinomics (2016), "Selecting Indicators to Measure Energy Poverty".
} 
were paying 10 years ago. ${ }^{98}$ It concerns affordability, and may invite a more long-term preventive approach, not always lying within the market context. For example, the amended Directive on the Energy Performance of Buildings includes provisions for investments in energy efficient housing that will help tackle energy poverty. ${ }^{99}$ In the same vein, France, Italy and Portugal have put in place specific energy efficiency measures, in the form of subsidies and tax reductions for vulnerable consumers. ${ }^{100}$

Other targeted measures addressing economic disability involve financial interventions through the social welfare system. ${ }^{101}$ These may be necessary where a high percentage of disposable income is needed to cover energy costs, or to address the needs of retired and unemployed. Such interventions may include social benefits, tax exemption (based on, for example, income or the geographical location of the beneficiaries) and direct payments. Tax schemes in particular, such as different energy taxes or exemptions, should however be compatible with state aid rules, as should subsidies.

Economic and/or physical disability may be addressed through price regulation, in the form of social tariffs, ensuring that vulnerable consumers can access the most affordable energy. ${ }^{102}$ A number of Member States has implemented such social tariffs. One option is to offer progressive tariffs whereby the more energy a consumer uses, the higher the tariff he pays. Alternatively some Member States offer lower tariffs for consumers who have a high-energy requirement. ${ }^{103}$

This section explored how the broader logic of reasonableness translates into the different affordability instruments enshrined in the EU energy acquis. It offered a taxonomy of these instruments by reference to whether they take place in the market or outside the market and their beneficiaries. In this regard, it distinguished between measures of general application such as retail price regulation and measures of targeted application. It also explored how the tension between the two shades of reasonableness is

\footnotetext{
${ }^{98} \operatorname{COM}(2016)$, “Clean Energy for All Europeans", 11.

${ }^{99} \operatorname{COM}(2016)$, "Proposal for a Directive of the European Parliament and of the Council amending Directive 2010/31/EU on the Energy Performance of Buildings'.

${ }^{100}$ See supra note 95.

${ }^{101}$ See e.g. Austria's Electricity Assistance fund, discussed in the Vulnerable Consumer Working Group Guidance Document, supra note 95.

${ }^{102}$ To this respect see Greece's social household tariff, Italy's social tariff for low-income families, Hungary's discount for large families discussed in the Vulnerable Consumer Working Group, supra note 95.

${ }^{103}$ Ibid.
} 
mediated through the lenses of the ECJ's "market participation test". The following section will integrate the different instruments for pursuing reasonable prices in al its various dimensions and will discuss their respective advantages and disadvantages, as there are perceived by EU law to draw some conclusions.

\section{The quest for reasonable prices: A comparative assessment of the different instruments and its implications for Member States' practice}

The two shades of reasonableness explored above revealed various instruments for achieving reasonable energy prices, as reflected in both its economic and non-economic understandings and dimensions. These range from consumer empowerment measures deriving from economic understandings of reasonableness and more direct consumer protection measures stemming from the conceptualisation of reasonableness as affordability. This section aims to draw some conclusions on how the EU framework perceives these instruments in a bid to generate insights into the way the it accommodates the disparate domestic regulation within the internal energy market and the concomitant tension between the two shades of price reasonableness.

As we already discussed, the EU framework seeks to mediate between the conflicting objectives and instruments underlying the two shades of reasonableness by providing some broad, albeit strict supervisory rules regarding the nature and degree of domestic intervention. Rather than one taking absolute precedence over the other, the two shades of reasonableness are in a constant dialectic relationship regulated by the principle of proportionally as the latter finds its expression in the ECJ's "market participation" test. In fact, as will be shown below, the latter has provided an overarching normative principle prescribing when, how and to what extent reasonableness as affordability should be triggered and the specific instruments thereof. The "market participation" principle has also been further strengthened in the recently announced "Winter Package", 104 that includes inter alia measures aiming at the increased participation of all consumers, including the vulnerable consumers. Four crucial conclusions flow from the closer

\footnotetext{
${ }^{104}$ All documents are published at: <http://ec.europa.eu/energy/en/news/commission-proposesnew-rulesconsumer-centred-clean-energy-transition> (last visit 10 October 2017).
} 
examination of the "market participation test" as a guiding principle for state intervention.

First, the EU's approach to price reasonableness embarks from the fundamental presumption that market forces and competition will deliver 'reasonable prices'. In both the Federutility ${ }^{105}$ and the ENEL produzione ${ }^{106}$ judgments discussed above the ECJ pronounced that the logic, purpose and scheme of the energy liberalisation directives requires that retail energy supply prices must be set by the market forces of supply and demand. This is the preferred option and overarching objective of liberalised retail energy markets. This conclusion is further supported by the strict conditions of necessity and proportionality that have to be met before intervening in the retail price setting.

Second, while not prohibited a priori and not per se illegal, as we explained, retail price regulation through PSOs is seen as a 'second-best' alternative, pursued to protect consumers whenever there is a general interest to be pursued. As advocated by Advocate General Colomer: "[T]he objective of preventing undesirable and disproportionate price rises which would be detrimental to consumers constitutes grounds for 'general economic interest' which, provided the directive's other conditions are met, would justify public intervention in respect of prices for the supply of natural gas." ${ }^{107}$ However, the "market participation" principle points towards strict regulation of such intervention. This is because regulated prices impede the development of retail competition by preventing market entry from new suppliers and thus reducing consumer's choice. This is especially the case when retail prices are set below costs, i.e. without taking into consideration wholesale market prices and other supply costs (i.e. when they are not fully costreflective). ${ }^{108}$ The Agency for the Cooperation of Energy Regulators (ACER) notes that this is the situation in a number of Member States where price-caps exist, as public authorities tend to set energy retail prices with greater attention to political considerations than to underlying supply costs. ${ }^{109}$ Furthermore, artificially low retail prices prompt consumers to disengage from the market. ${ }^{110}$ Additionally, regulated prices may

\footnotetext{
105 Case C-265/08, Federutility.

${ }^{106}$ Case C-242/10, ENEL Produzione SpA v Autorita per l'energia elettrica e il gas.

107 Opinion of A.G. Colomer in C-265/08, Federutility, EU:C:2009:640, para.56.

108 See ERGEG (2007), “End-user energy price regulation: An ERGEG Position Paper”, E07-CPR-10-03.

109 See ACER/CEER, op. cit. supra note 8.

110 Ibid., Section 8.2.
} 
negatively impact the consumers' propensity to switch. In the same vein, in the "Energy Union" communication, the European Commission identified regulated retail prices as an obstacle to demand-side participation and retail competition. ${ }^{111}$ In fairness, most countries with regulated prices have a dual market-structure in place where regulated and non-regulated prices coexist. In most cases where this duality exists, regulated prices (default tariffs) are available to all household consumers. However, this arrangement still impedes competition, as consumers tend to stick with the regulated tariff and do not switch to alternative tariffs. ${ }^{112}$ What is more, the option to switch to market prices still does not exist for household electricity and gas consumers in a handful of Member States. ${ }^{113}$

The bleak picture of national energy markets discussed above brings us to the third observation that relates to the strict application of the proportionality requirement. It is not sufficient for Member States to verify the existence of public interest, but domestic regulation should comply with the principle of proportionality, which implies, as we saw, that price regulation should be limited to the price component influenced by the specific circumstances, but not to the final end-user's price. Furthermore, the rationae personae limitations of such interventions imply that interventions can only survive when they concern targeted, and not blanket, retail price regulation. Thus, the normative guiding principle of "market participation" allows the EU to exclude large industrial customers from the reach of reasonableness as affordability instruments, subjecting these market actors to the default principle of economic reasonableness governed by market competition.

Fourth, delineating the scope of beneficiaries according to their ability to participate in the market and act as empowered consumers has crucial ramifications for a number of Member States which apply across the board retail price regulation without differentiating between household and industrial customers. The latest ACER Market Monitoring Report is particularly telling with regard to the pervasiveness of blanket retail price regulation: after eight years of full market opening, state regulation for household

${ }^{111} \operatorname{COM}(2015)$, "Communication from the Commission to the European Parliament, the Council, the European Economic and Social Committee of the Regions and the European Investment Bank, A Framework for a Resilient Energy Union with a Forward-Looking Climate Change Policy", at 2.2.

112 See ACER/CEER, op. cit. supra note 10, para. 137.

113 See e.g. Malta and Cyprus and for households gas consumers in Bulgaria, Greece, Latvia and Romania. 
customers still exists in 12 and 13 countries, respectively. ${ }^{114}$ In addition, several countries have regulated prices for industrial consumers. Following the Court's judgment in Federutility these are now difficult to justify. Furthermore, the Commission has expressed its opposition to blanket retail price regulation in several policy documents and insists on Member States phasing-out regulated prices, by establishing roadmaps. ${ }^{115}$ Roadmaps should contain clear and attainable steps to establish the necessary conditions for a well functioning market where there would be no end-user price regulation. The steps taken by the Member States during the transition period should be properly monitored at both national and EU levels via notification of the PSO to the Commission. Similarly to the Commission, the European Regulators Group for Electricity and Gas ("ERGEG") suggested that end-user price regulation should be either abolished or brought into line with market conditions. ${ }^{116}$ Finally, it is worth briefly mentioning that the Commission has also taken action to ensure that prices regulated at a level lower than market price do not amount to state aid within the meaning of Article 107(1). ${ }^{117}$

Fifth, the "market participation" test as regulated by the proportionality requirement allows us to further conclude that retail price regulation should be avoided in the face of a less restrictive alternative, such as taxation or social welfare measures. Indeed on protecting the vulnerable consumer, the Commission takes a clear stance against retail price regulation, while acknowledging the potential need for transitory social tariffs. There is a certain appeal on relying solely on social policy. First, such an approach safeguards the legitimacy of the NRA, which, as counter-majoritarian institutions, are thought to be ill suited in performing redistributive policies. Second, addressing the needs of vulnerable consumers outside the market context reduces distortions in market prices. Relatedly, it also alleviates the tension that exists between the NRAs competition

\footnotetext{
${ }^{114}$ See ACER/CEER, op. cit. supra note 8, at p. 46. Countries applying end-user price regulation in electricity are Bulgaria, Cyprus, Denmark, France, Hungary, Lithuania, Malta, Poland, Portugal, Romania, Slovakia and Spain. Countries applying end-user price regulation in gas are Bulgaria, Croatia, Denmark, France, Greece, Hungary, Latvia, Lithuania, Poland, Portugal, Romania, Slovakia and Spain.

115 The Commission, in its November 2012 Communication 'Making the internal energy market work", it emphasized that it would insist on phase-out timetables for regulated prices and continue to promote market-based price formation.

${ }^{116}$ See ERGEG (2007), supra n.108.

${ }^{117}$ For an analysis see Fischerauer and Johnston op. cit. supra note 20, pp. 470-2. See e.g. Commission Decision of 12 June 2012 on State Aid SA. 21918 (C 17/07) (ex NN 17/07) implemented by Franceregulated electricity tariffs in France [2012] O.J. 2012, C 398/10.
} 
objective and social objectives, which have gradually brought regulators closer to the traditional concerns of government. ${ }^{118}$ However, this can be criticized on the basis that the costs of such policies are to be borne almost entirely by Member States, many of which currently face major fiscal constraints. It can also be challenged on the basis of the various difficulties that exist in targeting the consumer in need, given the multifaceted nature of consumer vulnerability. Regarding the latter, the "Winter Package" contains provisions relating to information gathering and dissemination measures to better appreciate consumer vulnerability. It is further suggested that Member States shall also define a list of indicators for measuring energy poverty as well as monitoring the households in energy poverty and report on relevant measures to the Commission every two years. ${ }^{119}$

The interpretive note on retail markets concedes that social policy and energy policy including energy efficiency measures can interact to protect vulnerable customers. ${ }^{120}$ However, it clarifies that the intention is not for energy policy to substitute the protection of vulnerable consumers through social policy and the measures taken to protect consumers through the market must not interfere with either market opening or the functioning of the market. This is a quite challenging task, however. First, regulators' duties relating to the protection of vulnerable consumers may be in direct conflict with their competition objective. Second, NRA's governing statutes do not always indicate how or to what extent regulators should support vulnerable consumers. An integrated approach, whereby social policy interacts with energy policy, aiming at reducing consumption and improving efficiency may allow for a more equitable outcome for vulnerable consumers. Regarding the latter, the Energy Efficiency Directive specifically refers to the need of supporting vulnerable consumers and encourages Member States to take it into account when devising energy efficiency obligation schemes and alternative measures to achieve energy savings. ${ }^{121}$ The "Winter Package" also includes proposed changes to the Energy Efficiency Directive so as to further empower and protect

\footnotetext{
${ }^{118}$ For an analysis see Vibert, The New Regulatory Space: Reframing Democratic Governance (EE, 2014).

119 Art. 29, COM(2016), "Proposal for a Directive of the European Parliament and of the Council on common rules for the internal market in electricity" (Brussels, 30.11.2016).

${ }^{120}$ Interpretive Note, supra note 92 , at 4.4.

121 See Art. 7a; 7b of Directive (2012/27/EU) of the European Parliament and the Council of 25 October 2012 regarding energy efficiency, amending Directives 2009/125/EC and 2010/30/EU and repealing Directives 2004/8/EC and 2006/32/EC, O.J. 2009, L. 315/1.
} 
vulnerable consumers. ${ }^{122}$ These should be viewed in light of the overall key goal of the suggested proposals, namely to enable all consumers to fully participate in the energy transition, to manage their consumption, to deliver efficient solutions which save them money and to contribute to an overall reduction in energy consumption.

The abovementioned findings on the significance of the "market participation" approach as a useful tool for mediating between the two shades of reasonableness enshrined in the EU energy acquis are somewhat reflected in the recently announced "Winter Package". Besides the Commission's commitment to completely phase out regulated prices in the new energy market design, most interestingly, the Recast Directive on common rules for the internal market in electricity ${ }^{123}$ goes a step further and reconsiders the relevance and scope of affordability instruments, such as the PSOs relating to the price of supply. In particular, it is strongly suggested that PSOs in the form of supply price regulation supply should no longer be pursued by Member States as their effects blatantly reflect those of blanket retail price regulation. ${ }^{124}$ On the contrary, "Member States should apply other policy tools, and in particular targeted social policy measures, to safeguard the affordability of electricity supply to their citizens" ${ }^{125}$ with price regulation being applied "in limited exceptional circumstances". 126

\section{Conclusion}

The article advanced the proposition that exploring what constitutes a reasonable price for energy in the current paradigm of liberalisation is a necessary precondition for assessing the appropriateness, nature and conditions of state intervention in retail energy prices. By distinguishing between the notion of reasonableness in light of the market competition objective and reasonableness as affordability, the article brought into greater focus the various instruments that are enshrined in the energy directives for pursuing

\footnotetext{
${ }^{122} \operatorname{COM}(2016)$, "Proposal for a Directive of the European Parliament and of the Council amending Directive 2012/27/EU on Energy Efficiency".

${ }^{123} \operatorname{COM}(2016)$, "Proposal for a Directive of the European Parliament and of the Council on common rules for the internal market in electricity" (Brussels, 30.11.2016).

${ }^{124}$ Ibid.,Recital 14 (new)

${ }^{125}$ Ibid.

${ }^{126}$ Ibid. Recital 14; Art.5(2)-(4).
} 
reasonable prices; not necessarily exhausted in retail price regulation. Consumer empowerment measures can and should also be relied upon to deliver reasonable prices, especially in light of the anticipated "consumer centred clean energy transmission" announced in the Commission's "Winter Package". The article also examined the respective advantages and disadvantages of all the different measures envisioned by the EU energy acquis from the point of view of the EU framework and showed how the tensions between the two shades of reasonableness are accommodated in the broader EU constitutional and institutional context. In doing so it elaborated on the "market participation" principle implicitly put forward by the ECJ in a bid to guide the Member States as to when and how they should intervene in the process of competition.

Despite the renewed emphasis on consumer empowerment in the Commission's rhetoric, the old and still on-going battle between the Commission and the Member States ${ }^{127}$ around the scope and conditions of retail price regulation forms a nagging reminder of the contradictions that exist within the EU's commitment to "open and undistorted competition" in essential services such as energy supply. Economic understandings of price reasonableness underpinned by economic efficiency considerations cannot alone and/or always guarantee "reasonable prices". However, the various social concerns underpinning understandings of reasonableness as affordability are mostly national in origin and may contribute to a further fragmentation of national energy markets putting the overall objective of an internal energy market at risk. The way EU law attempts to reconcile and resolve the tension between the two shades of reasonableness reflects pragmatic considerations about the plurality of interests, goals and values pursued in manufacturing an EU energy markets. These make it highly unlikely that a single shade of price reasonableness will ever prevail. Nonetheless, before resorting to interventionist measures, Member States should be guided by a better

\footnotetext{
${ }^{127}$ Not least reflected in the number of infringements proceedings the European Commission has initiated against Member States over the past decade (2006, 2009, 2012). See European Commission, "Infringement procedures opened in the gas and electricity market sector, by Member State", MEMO/06/152 (Brussels, 04.04.2006) and European Commission, "The Commission takes action against Member States which have not opened up their energy markets properly", IP/06/430 (Brussels, 04.04.2006). See further European Commission, "Commission brings actions before the Court of Justice against several MS for incorrect transposition of Electricity and Gas Directives", IP/08/855 (5.6.2008, Brussels); European Commission, "Commission acts to ensure effective and competitive energy market across Europe", IP/09/1035 (25.6.2009, Brussels).
} 
understanding of the two shades of reasonableness and their concomitant consumer empowerment and consumer protection measures, as brought forward in this article. Otherwise, retail price regulation is likely to remain a persistent "anachronism" 128 in the EU' liberalised retail energy market.

${ }^{128}$ See Fischerauer and Johnston op. cit. supra note 20. 